\title{
The Art of Ephemera: typographic innovations of nineteenth-century midland jobbing printers
}

\author{
David Joseph Osbaldestin
}

School of Visual Communication, Birmingham Institute of Creative Arts, Birmingham City University

Centre for Printing History and Culture, Parkside Building, 4 Cardigan Street, Birmingham, B4 7BD, UK. david.osbaldestin@bcu.ac.uk

\section{Biography}

David Osbaldestin is Deputy Course Leader of Graphic Communication at Birmingham City University (BCU) and has taught internationally for nineteen years. He is currently a $\mathrm{PhD}$ candidate at $\mathrm{BCU}$, investigating the sans serif in nineteenth-century printed ephemera with particular reference to Birmingham and the Midlands. David is a member of the executive group of the Centre for Printing History \& Culture (CPHC); Honorary Treasurer of the Printing Historical Society (PHS); convener for Print Networks (PN); and a practising visual communicator. 


\begin{abstract}
During the nineteenth century jobbing printers in Britain played an important role in the history of printing. In the skilled hands of the provincial printer, new display types were composed into new forms of advertising, contributing to the education and societal orientation of the emergent middle classes. Jobbing printers of the Midlands contributed to the advancement of British typography, working with new foundry types-sometimes before their appearance in foundry specimen books-and by making significant innovations in the composition of printed ephemera. This article considers the craft and invention of three influential nineteenth-century jobbing printers in the region: William Joesbury (1838-1919) of Birmingham, and the two members of the Gitton family, George (1746-1825) and George Robert (1801-85) of Bridgnorth. Joesbury printed Timothy Worsey Watton's Outline Charts of General History (1848), an early example of progressive visual education for grammar schools; and the Gittons printed ephemera of Bridgnorth is a valuable record of the town's importance as centre of industry and of its social culture.
\end{abstract}

\title{
Keywords
}

Bridgnorth, Birmingham, ephemera, George Gitton, George Robert Gitton, jobbing printing, Joesbury, sans serif, typography, Watton 


\section{Introduction}

In the nineteenth century trade flourished in the Midlands through the exchange of goods that were transported across the region's canals, turnpikes and rail networks. Increasingly commerce and industry needed to connect with suppliers, customers and competitors, and this stimulated a revolution in the way businesses communicated through print. Printed products also contributed to the region's social, cultural, political, and economic life through advertising material and other forms of printed communication which were produced by a rising number of 'jobbing printers' who increasingly issued commercial and display work rather than books or newspapers. ${ }^{1}$ The nineteenth-century Midland printing trade comprised a large network of small-scale jobbing print shops which coexisted economically, sometimes collaborating on work and sharing their resources. ${ }^{2}$ The nature of what they produced, and the design of what they printed, transformed how information and ideas were exchanged: the ephemera that has survived records these changes.

Nineteenth-century printed ephemera was characterised by the use of a new range of fashionable typefaces known collectively as 'display faces' that were intended for use in large sizes and for headlines, rather than extended passages of text. Display faces included fat faces, antiques, Egyptians and sans serifs which were specifically designed to serve the emerging needs of advertising, and made for use in posters, playbills, broadsides, lottery tickets and other printed

\footnotetext{
1 Jobbing printers focused on commercial work such as advertising as opposed to printing books and newspapers.

${ }^{2}$ C. Archer,' Printing and the printed word', in Birmingham Workshop of the World, ed by Malcolm Dick \& Carl Chinn (Liverpool: Liverpool University Press, 2016) pp. 261-82; C. ArcherParre, 'Places and space of the printing press: trade interactions in Birmingham', in this volume; J. Hill, Bookmakers of Old Birmingham: authors, printers and book-sellers (Birmingham, 1907).
} 
ephemera. ${ }^{3}$ Display faces were intended to capture attention, and their popularity resulted in Britain making a unique contribution to typeface design. These typefaces were products of the industrial revolution and urbanisation, and contributed to the development of advertising, which competed for readers' attention not only through the smog of polluted urban areas but also the visual pollution of mass communication.

Sans serif typefaces were particularly significant in the nineteenth century. The world's first sans serif printing type, Two Lines English Egyptian, was issued by the English typefounder William Caslon IV (1780-1869), in $1816 .{ }^{4}$ Although released in 1816, and first advertised in Caslon's 1818 specimen book, the sans serif was slow to be manufactured by other typefounders and did not come into common usage until the mid-nineteenth century. The London typefounder Vincent Figgins (c.1799-1860) released a sans serif in 1830, followed by William Thorowgood (d.1877) in 1832. ${ }^{5}$ By the latter half of the century the sans serif had taken hold and there were hundreds of different variants issued by the leading typefounders.

The sans serif can be regarded as one of the most important typographic developments of the nineteenth century. From its slow development at the beginning of the 1800s, it grew to become the leading display typeface used in advertising and information design. The introduction of the sans serif certainly 'changed the character of design

\footnotetext{
${ }^{3}$ Fat faces are advertising types characterised by an extreme contrast between the thick and thin strokes of the characters. Antique was a term used by British and American typefoundries for slab serif printing types, these are typefaces with terminated by thick block-like serifs. In France, the term Antique refers to sans serifs. Slab serif letterforms were first known in France and Germany as Egyptienne. Conversely, Thorowgood named his slab serif an Egyptian, and Caslon IV named the first sans serif Egyptian. The sans serifs are letter forms without serifs, early British sans serifs were known as Grotesques and were monoline linear characters. 4 'William Caslon IV', in Printers (Oxford, UK: Bodleian Library), in The British Book Trade Index <http://bbti.bodleian.ox.ac.uk/details/?traderid=12596> [accessed 20 March 2020]. ${ }^{5}$ J. Mosley, The Nymph and the Grot, the Revival of the Sanserif Letter(London: Friends of St Bride Printing Library, 1999), p. 56.
} 
entirely', and these bold types, originally created for use in lottery bills and poster advertising, were later applied to information design such as railway timetables and dictionaries. ${ }^{6}$ At the same time there was a radical shift in the typographic composition of advertising material, and sans serif typefaces were linked to new ways of presenting information for the reader. As a result of an increased volume of printed material a new sort of typography emerged enabling readers to speedily access information and differentiate between editorial and advertising. In turn, this stimulated a market for display faces. These new, bold and often condensed sans serif typefaces not only saved on space but also enabled new ways of reading at speed.

This article considers innovations in the use of sans serif typefaces by nineteenth-century midland jobbing printers. By examining the ephemera produced by these printers, this article demonstrates their typographic inventiveness and argues that Midland printers were working ahead of fashion with their experimental designs and use of new typefaces, particularly the sans serif. This article presents two typographically progressive printers: the Birmingham printer William Joesbury (1838-1919), whose contribution to the printing of Timothy Watton's Outline Charts of General History (1848), was an early example of the use of sans serif types in education design; and the Shropshire printers George Gitton (1746-1825) and George Robert Gitton (1801-85), whose printed ephemera used the latest typographic fashions to communicate everyday news to the people of Bridgnorth.

\footnotetext{
${ }^{6} \mathrm{M}$. Twyman, 'The Bold Idea: the use of bold-types in the nineteenth century,' Journal of the Printing Historical Society, 22 (1993), 135.
} 


\section{Printed ephemera: sources and resources ${ }^{7}$}

For the purpose of this article printed ephemera are mostly single-sided documents produced in many formats from large scale theatrical playbills to small bookplates, generally printed in one or two colours, using a variety of display types. The quality of paper and the presswork varies across different forms of ephemera, from trade cards printed on thick pasteboard to handbills on cheaper coarse woven paper. There are many high-quality extant examples of nineteenth-century ephemeraboth in terms of printing and innovative use of typography-which survive in public and private collections and which cover a wide range of different classes of printed documents. The most significant collections of nineteenth-century midland printed ephemera identified for this article are located in the Birmingham Archives \& Collections; the Cadbury Research Library, University of Birmingham; the Shropshire Archives; and the John Johnson Collection, Bodleian Library, Oxford. The Wolfson Centre for Archival Research holds a collection of eighteen scrapbooks of printed ephemera from the 1790 s to 1940 s. $^{8}$ The scrapbooks are important because they bring together printed material from many sources, and with different contents, into one place. They include material relating to political ideologies which were recorded through leaflets promoting public lectures, documents regarding the opposition, pamphlets in support of laws, and fliers advocating voting rights for women. They cover a wide range of social history including ephemera relating to the civic governance of Birmingham, policing, the

\footnotetext{
${ }^{7}$ J. Lewis, Printed ephemera: the changing uses of type and letterforms in English and American printing, (London: Faber \& Faber Limited, 1969), p. 4; M. Rickards, This is Ephemera (Gossamer Press, 1977); M. Rickard, Encyclopedia of Ephemera (London: The British Library, 2000); M. Twyman, John Soulby, Printer, Ulverston (Reading: The University of Reading, 1966); M. Twyman, Printing 1770-1970: an illustrated history of its development and uses in England, (London, Eyre \& Spottiswoode, 1970). ${ }^{8}$ Birmingham Archives \& Collections (BA\&C), LS 12, Birmingham Scrapbooks, Vol 1-18, A collection of leaflets, circulars, posters, cuttings etc., 1791-1940s.
} 
expansion of the city's infrastructure, transport networks, sanitation and utilities, and the health and education of the population. They also include printed material produced by religious groups and churches in the city. In addition, the scrapbooks show examples of ephemera that relate to significant cultural attractions in Birmingham, and record different forms of entertainment available to the growing middle classes: from announcements for both the Theatre Royal and the Gaiety Theatre, through to posters promoting public sporting events. The scrapbooks also contain material relating to the town's trades, products and services including printed adverts, catalogues, directories and trade cards. Other material includes bound volumes of nineteenth-century broadsheets organised under the themes of crime, politics, religion, and entertainment; documents relating to the Birmingham Political Union, collections of material from the Women's Social \& Political Union, and the Wingate Bett collection of transport tickets, and miscellaneous business ephemera.

Printed ephemera in the Cadbury Research Library (CRL), University of Birmingham (UoB), complement the material at the Library of Birmingham. In particular there are examples of the sans serif used for information design, such as a first edition of Timothy Watton's educational charts from 1848, which show an application of Caslon's early sans serifs, and Major James Bell's $A$ View of Universal History, (1842). ${ }^{9}$ These texts provide evidence of new ideas in nineteenth-century typographic design. The CRL also houses a large selection of jobbing printing, with surviving examples of the work of George Gitton of Bridgnorth, alongside playbills for the Theatre Royal,

\footnotetext{
${ }^{9}$ T.W. Watton, Outline charts of general history, in large type adapted to class teaching, and for general use, (London, London : Whittaker and Co., 1848); J. Bell, View of Universal History, Literature and the Several Schools of Painting, 5th ed, (London: London : printed by T.C. Hansard, for the Author, 1842.
} 
Birmingham, and a collection of over 100 theatre programmes from London and the Midlands.

The Shropshire Archives hold printed ephemera and other material produced in Bridgnorth by Gitton printers. ${ }^{10}$ It includes George Gitton's scrapbook from 1812-22, and his printer's file (a guard book containing chronologically ordered examples of his printing, 1820-25). ${ }^{11}$ In the Bridgnorth Public Library there are transcriptions of George Robert Gitton's diaries of 1838 and 1859, recording his finances, alongside his personal observations. The diaries evidence Gitton's printing output and give insight into the collaborative workings of a nineteenth-century printer.

Located in the Bodleian Library, Oxford, the John Johnson Collection is 'one of the most important collections of printed ephemera in the world and generally regarded as the most significant single collection of ephemera in the UK' ${ }^{12}$ It is a valuable repository for Britain's paper heritage and contains a wide array of rare and unusual materials, including printed ephemera produced by several Bridgnorth printers working in the town at the time of the Gittons. ${ }^{13}$

In preparing this article, the examples of printed ephemera were compared to surviving copies of typefounders' specimen books in the both St Bride Library and the British Library, London. Printers type specimens give insight into nineteenth-century typographic developments. Produced as sales catalogues, the specimen books presented the latest range of printing types. They reflect contemporary

\footnotetext{
${ }^{10}$ Shropshire Archives (SA), 3217/29, Morley Tonkin Collection, A collection of poems, anecdotes etc. George Gitton, 1812-1822; SA, 4752/94/1, Nock, Deighton Collection, Gitton's Printing Office - broadsheets, public notices etc., 1820-25.

${ }^{11}$ M. D. G. Wanklyn, The Diary of George Gitton of Bridgnorth for 1966, (Shrewsbury, University of Keele, 1998).

${ }^{12}$ Bodleian Library (Bod), 'The John Johnson Collection,' <http://johnjohnson.chadwyck.co.uk/marketing/about.jsp> [accessed 24 January 2020].

${ }^{13}$ Bod, Bridgnorth Collection III.C., G. Gitton \& G.R. Gitton Playbills, 1795-1839.
} 
typographic fashions through the breadth of new typefaces, and show the changing economic demands through the quantity of new display types produced in a wide range of weights and sizes. The new display types advertised in typefounders' specimen books are evident in the printed ephemera of the Midlands, including some examples that predate the publication of foundry specimen books. The type specimen books show that regional printers were following the latest typographic fashions and were keeping pace with London.

\section{Birmingham printers and their printed products}

By the nineteenth century, Birmingham had made outstanding contributions both to the Enlightenment and the Industrial Revolution. Its geographical connection to the Black Country and surrounding towns positioned Birmingham at the economic heart of the West Midlands, and an important centre in the global economy. Its reputation was built on manufacturing, politics, religion, social reform and cultural activity. The town saw rapid expansion during the early nineteenth century and both its economic success and growing reputation attracted migrant workers. Between 1801 and 1851, its population grew from 75,000 to 247,000 and in the second half of the century it doubled in size to 522,000 inhabitants to become the second largest urban centre outside London. ${ }^{14}$ Known locally as the 'Midland metropolis' and celebrated as the 'city of a thousand trades', its industry was built on metalworking through the production of small-wares such as nails, screws, buttons, pins and nibs, by specialist craftsmen including gunsmiths and jewellers. ${ }^{15}$ Birmingham wares were famous around the

\footnotetext{
${ }^{14}$ S. Gunn, The Public Culture of the Victorian Middle Class: Ritual and Authority in the English Industrial City: 1840-1914 (Manchester: Manchester University Press, 2008), p. 11. ${ }^{15}$ C. Hall, Civilising Subjects: Metropole and Colony in the English Imagination 1830-1867, (Cambridge: Polity Press, 2002), p. 21; M. Berg, 'Commerce and creativity in eighteenth-century
} 
world, they contributed towards its economic expansion, and the town was celebrated as 'workshop of the world'. ${ }^{16}$ The town's traders needed to exchange information with each other, and goods and ideas had to be promoted both at home and abroad; in addition the town needed to communicate not only with an expanding domestic population but also the world beyond its boundaries. ${ }^{17}$ This increase in industrial productivity and social activity stimulated a demand for printing and a commensurate growth in number of jobbing printers.

Between 1816 and 1851 there were 693 printers operating in Birmingham, of which 388 were copperplate engravers; the remainder were probably letterpress printers as this was the predominant printing technology of the period. ${ }^{18}$ The town had a particularly high proportion of engravers, who applied their skills to promote the town's wares and manufactories particularly through the production of trade cards and directories. The directories are typographically notable. Wrightson \& Webb, publishers of the Directory of Birmingham, were located in the 'Athenaeum' works on New Street, where they traded as bookbinders, booksellers, stationers, printers, account-book manufacturers, copperplate printers, letterpress printers, wholesale paper merchants and publishers. Their 1847 Directory was a typographically innovative departure from previous editions. ${ }^{19}$ The printing is well-executed and its application of new display faces demonstrates the printer's awareness of new trends. The full-page advertisements explore new approaches in the use of visual hierarchy, and the traditional linear method of reading is

\footnotetext{
Birmingham', in Markets and Manufacturers in Early Industrial Europe (London: Routledge, 1991) pp. 181.

${ }^{16}$ A. Briggs, Victorian Cities (London: Penguin Books, 1968), p. 184.

${ }^{17}$ E. Hobsbawm, Age of Capital 1848-75(Orion, 2010), p. 67.

18 'Letter', in Birmingham Printers (Oxford: Bodleian Library), in The British Book Trade Index $<$ http://bbti.bodleian.ox.ac.uk > [accessed 20 March 2020].

${ }^{19}$ Cadbury Research Library (CRL), DA690.B6, Wrightson \& Webb, The directory of Birmingham; including an alphabetical list of the principal inhabitants of the town, 1847.
} 
disrupted by bold sans serif types emphasising the manufacturers' trade names and directing the reader's attention to the message. Other directories of this period are typographically more arbitrary-a characteristic of jobbing printing-selecting founts based on availability rather than suitability. In their full-page advertisements Wrightson \& Webb used sans serif typefaces to reinforce key information, thereby enabling a quick reading of the text.

This new use of visual hierarchy and information design was also used to great effect by the Birmingham printer William Joesbury (1815-92), in his printing of Timothy Watton's educational charts. William Joesbury was the son of local engraver Joseph Joesbury (17951858). William was a wholesale stationer, bookbinder, copperplate printer, engraver/etcher, librarian, circulating library owner, bookseller, and letterpress printer. He also acted as a commercial agent, printing and selling tickets and bills for travel excursions. Joesbury traded variously from Vauxhall Street and Aston Street and operated under several business names including the Styled Eagle Press (1850-59), Joesbury's Steam Press (1859-89) and finally in partnership with his son, Franklin, as Joesbury \& Son (1889-1919). ${ }^{20}$ The business was finally taken over by Robert Aldred Marshall in $1881 .^{21}$

Timothy Worsey Watton (1811-99) was master of King Edward's School, Gem Street. A gentleman of note, Watton was recorded in several local directories of the period, including Wrightson \& Webb's Birmingham Directory (1847) and Francis White \& Co.'s History, Gazetteer, and Directory (1850). Watton was the author of ten historical charts which were printed by Joesbury in Birmingham and circulated by Whittaker and Co., London, and Oliver and Boyd, Edinburgh. A review in the Liverpool Mercury of October 1849 claimed 'no Library should be

\footnotetext{
${ }^{20}$ 'Joesbury', in Birmingham Printers (Oxford: Bodleian Library), in The British Book Trade Index http://bbti.bodleian.ox.ac.uk [accessed 27 March 2020].

${ }_{21}^{21}$ 'Notices', London Gazette, 21 June 1881.
} 
without one, as at a trifling expense, it supplies an important work of ready reference, giving data from the Creation to the present time'. ${ }^{22}$ The sheets were folio size, sold for $4 s$ per set in stiff covers, or $6 d$ per chart, and they were advertised in 'large type' adapted for class teaching and private use.

A precursor to Watton's educational charts, was the publication of Major James Bell's fifth edition of A View of Universal History, printed in 1842 by T. C. Hansard, London. In twenty-five large-scale coloured chronological tables, Bell attempted to map-out the major achievements of all human history, literature and art across the continents. Bell's use of bold types for emphasis replaced the earlier tradition of using Old English characters. To present this complex data, Bell designed new ways of organising tabular information, by grouping information both vertically and horizontally, and using contemporary display types for non-linear reading and quick reference. Intended for use in his own lectures and for educational purposes, Bell introduced a variety of typographic styles to 'afford greatly increased Advantages of Attraction to Vision, and consequent Impression on Memory'. ${ }^{23}$ Bell's complex system for connecting chronological and historical information is easy to read through its use of sans serif types for emphasis. The text follows a logical structure, using a consistent weight of sans serif type for key information, enabling the eye to move across the page at speed, travelling between points of interest and returning to make connections between the information found. Bell use of 'variegated forms of types' was sculptural and the contrasting styles and weights of display faces created a three-dimensional effect on the page. Hand-colouring was introduced in his fourth edition, in order to improve the 'Faculties to

\footnotetext{
${ }^{22}$ Caption from bookplate. T. Watton, Outline Charts of General History (Birmingham: W. Joesbury, 1848).

${ }^{23}$ Bell, p. 9.
} 
Memory, Rapidity of Reference, and Study'. ${ }^{24}$ Bell's tables were a key innovation in the development of information design and the use of bold types facilitated speed of reading and reference.

Watton's educational posters take cues from Bell's tables. Produced for use as teaching aids in the classroom, Watton's Outline Charts of General History (1848) used the early sans serif printing types from the London foundries of Blake \& Stephenson and Vincent Figgins. Watton's charts were inspired by the visual hierarchy found in printed advertising with their bias for sans serif headings. The charts were forerunners to the educational publishing experiments at the end of the century when display types were used to enable children, when learning to read and write, to make stronger visual connections through simple letterforms.$^{25}$ The generous use of white space employed in the charts was also a radical departure from the density of information presented in Bell's educational tables. The Charts, intended to be used as posters in the classroom, reflect the open visual hierarchy used in advertising posters, in a streamlined presentation of key dates and events which were regarded as foundational knowledge by Watton. By transforming the compositional structures of advertising into the classroom, Watton and Joesbury were innovators in the field of educational publishing.

Amongst the sans serif typefaces that Joesbury deployed in Watton's educational charts, was English Two Line Sans-Surryphs a direct descendant of the first ever sans serif Two Lines English Egyptian produced by William Caslon IV in $1816 .{ }^{26}$ Here 'English' refers to the size of the type, which is equivalent to twenty-eight points. English Two Line Sans-Surryphs was used by Joesbury to differentiate between sub-

\footnotetext{
${ }^{24}$ Bell, p. 9.

${ }^{25}$ S. Walker, 'Letterforms for handwriting and reading', in Typography Papers: Number 7 (London: Hyphen Press, 2007), p. 84.

${ }^{26}$ St Bride Library (SBL), Accession no. 6027, Blake, Garnett and Company, $A$ specimen of printing types, etc. by Blake, Garnett and Co., successors to Mr W. Caslon, of London, 1819.
} 
headings and historical categories. This is a scarce and early example of sans serif types being used as part of an integrated and considered design across a complete set of educational material, as opposed to being used in isolation as a typographic novelty. It is also rare evidence of Caslon's sans serif types in use. The Charts are, therefore, of great significance.

\section{FLOWERS DRAWN FROM NATURE. BEAUTIFUL VARIETIES. DIAMOND POCKET DICTIONARY.}

Figure 1: English Two Line Sans-Surryphs, Specimen of Printing Types, Blake, Garnett \& Company, 1819, St Bride Library, London. 


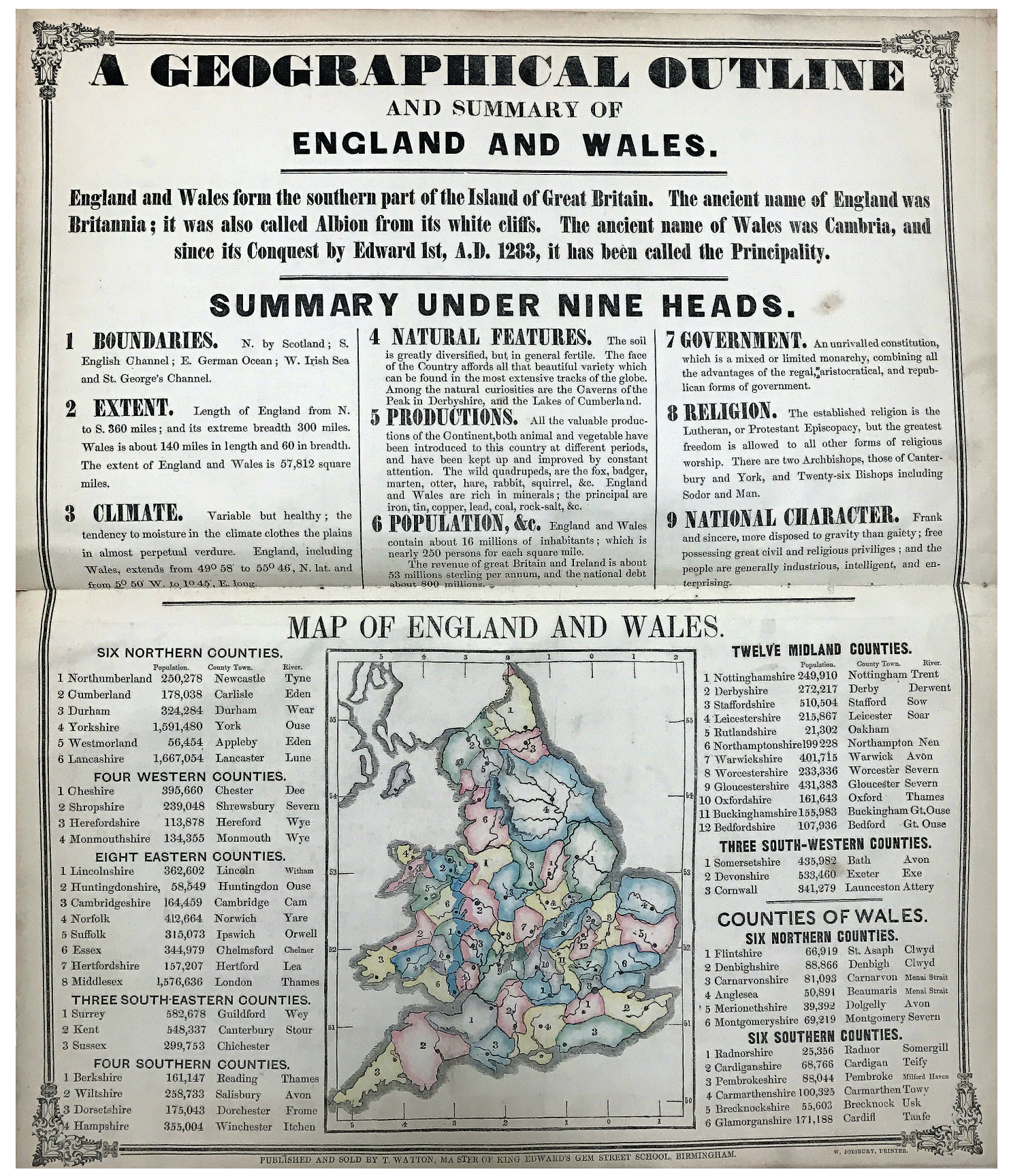

Figure 2: A Geographical Outline of England and Wales, Outline Charts of General History, Timothy Watton, 1848, Cadbury Research Library: Special Collections,

University of Birmingham.

In Watton’s chart for a 'Geographical Outline of England and Wales' the main headings were set in Blake \& Stephenson's Double Pica, no.2, a two-line fat face, with extreme contrast between the thicks and 
thins of the vertical strokes. ${ }^{27}$ For the subheadings Joesbury complements the heavy weight of the fat face types with Figgins's TwoLine Great Primer of $1832 .{ }^{28}$ This bold and geometric uppercase sans serif was applied to descending levels of headings, and used to great effect to guide the reader through the different levels of information. Blake \& Stephenson's Nonpareil Two Line Sans-Surryphs (12 point) and the larger sized English Two Line Sans-Surryphs (28 point) were also used to great effect to draw attention to important information and were balanced by a condensed sans serif Bourgeois Two Line Condensed Sans-Surryphs (9 point) that added weight to the composition and guided the eye across the chart. ${ }^{29}$

There are numerous examples of Birmingham's jobbing printers exploring new and experimental applications of sans serif types. In 1854, John Tonks of New Street followed Joesbury's use of space in a programme of musical entertainment at the Town Hall. Promoting two grand concerts performed by the celebrated French conductor Louis Jullien, Tonks used uppercase sans serif types and white space to give emphasis to the leading artists. These techniques were refined and advanced by other local printers. Frederick Turner, printer, bookseller and cheap music warehouse at 3 Snow Hill, used Blake \& Stephenson's Ten Lines Sans-Surryphs Ornamented (1839), in his playbills for the Theatre Royal. ${ }^{30}$ Turner's use of this sans serif dominates the

\footnotetext{
${ }^{27}$ SBL, Accession no. 20268, Stephenson, Blake and Company, Specimen of printing types, 1832.

${ }^{28}$ SBL, Accession no. 22224, Vincent Figgins, Specimen of printing types, 1832.

${ }^{29}$ SBL, Accession no. 20262, Stephenson, Blake and Company, Specimen of printing types, 1838.

${ }^{30}$ Birmingham: history and general directory of the borough of Birmingham (Birmingham: White, Francis \& Co., 1849); SBL, Accession no. 6409, Stephenson, Blake and Company, Specimen of printing types, 1839; British Library (BL), General Reference Collection DRT Digital Store Playbills 193, A collection of playbills from Theatre Royal, Birmingham, 1845.
} 
composition of the playbill. An uppercase wooden type, 120 points in size (approximately four centimetres), drew the viewers' attention to the names of the leading actors. Unlike other sans serifs, Ten Lines SansSurryphs Ornamented was decorated with a series of concentric lines that created the illusion and weight of a three-dimensional form.

The works of Joesbury, Tonks and Turner, demonstrate the innovation of Birmingham jobbing printers and their use of bold types and compositional space. Prior to Joesbury, sans serif types were used in moderation in educational documents, often at small sizes. Joesbury challenged this trend and brought them to the fore of the typographic content rather than a subsidiary role; in so doing he paved the way for other printers to follow suit.

\section{The Gittons and Bridgnorth}

Bridgnorth during the mid-nineteenth century was a middle-sized market and commercial town with an average population of 5,275 people. The wealth of the town was built on its river trade and its markets. Bridgnorth operated as a major inland port for the transport of goods from the potteries in Staffordshire to the sea port of Bristol and beyond. It was divided into the wealthy parish of St Leonard's in the high town with its market place and St Mary's on the river in the low town. The river trade began to decline with the opening of the railway in 1862, and in 1895 the last barge came down the river. Despite its modest size the economy of the town provided enough work for fourteen printers during this period. ${ }^{31}$

The printed ephemera of Bridgnorth record a large volume of documents relating to entertainment. This takes the form of theatre playbills and advertising handbills for the Bridgnorth races. In the

\footnotetext{
${ }^{31}$ D. R. Mackarill, 'George and George Robert Gitton Printers Bridgnorth', in Journal of the Printing Historical Society, NS, No. 4 (London: PHS, 2002), p. 56.
} 
nineteenth century Bridgnorth was a destination for leisure tourism, and the two entertainments were interconnected, with two different plays performed each day during the races. ${ }^{32}$ Horse racing began at Morfe Common (1690-1811), later moving to Innage (1812-39), where the last race meeting was held in June $1839 .^{33}$

Theatre manager and comedic actor Charles Stanton (1768-1838) had a longstanding relationship with the town. G. Gitton and G. R. Gitton both printed playbills for Stanton's performances. He opened the Cockpit Theatre in 1811, performing an average of three shows a week; admission cost a shilling in the gallery and two shillings in the pit. ${ }^{34}$ The theatre was used for cockfighting in-between productions. In 1824, the theatre moved to a new building on West Castle Street and re-named, New Theatre. Stanton continued to entertain the people of Bridgnorth until 1838, when his 'worldly' form of theatre fell out of fashion in favour of Music Hall style entertainment. ${ }^{35}$ The theatre continued without Stanton until it was demolished in 1850 , to make way for the Newmarket buildings. The Cockpit building was later preserved in 1958, as a Grade II listed building, and reconstructed at Avoncroft Museum of Historic Buildings in $1979 .{ }^{36}$

The Gittons did not have a monopoly on the printing of Stanton's advertising: Benjamin Partridge printed playbills for performances in the Cockpit Theatre in 1821; as did Gitton and Smith in

\footnotetext{
${ }^{32}$ CRL, PN 2596.B65, Bridgnorth Playbills Collection, New Theatre, Bridgnorth, 1832.

${ }_{33}$ 'Gazetteer of Racecourses', in Shropshire History<

http://shropshirehistory.com/other/racing.htm> [accessed 27 March 2020].

${ }^{34}$ Bod, Bridgnorth Collection III.C. (7), The John Johnson Collection, Playbill printed by G.R. Gitton for The Stranger, 1819.

${ }^{35}$ C. F. Gwilt, $A$ History of the Theatres of Bridgnorth (Bridgnorth: Self-published, n.d.).

${ }^{36}$ 'The Cockpit Theatre', in About Bridgnorth <https://www.aboutbridgnorth.com/the-cockpittheatre/> [accessed 11 December 2019].
} 
1837. ${ }^{37}$ In 1867, the Agricultural Hall opened, which included the Theatre Royal, with playbills printed by Clement Edkins (trading in Bridgnorth between 1849-80s) who succeeded his father's business of Edkins and Son $(1839-50) .^{38}$

\section{The Gitton Printers}

George Gitton (1750-1825) was the first printer in Bridgnorth; prior to setting up his press, printing work was carried out in Wolverhampton or Ironbridge. Gitton was apprenticed to Benjamin Haslewood in 1762. As a letterpress printer, bookseller, stationer, newsagent and postmaster he apprenticed five boys during 1792 and $1802 .{ }^{39}$ His scrapbooks signal that he was an enlightened man, recording and commenting on daily news, poetry and religious texts. His printer's file (1820-25) contains a large collection of ephemera documenting the everyday life in Bridgnorth. The documents each have handwritten notes on the quantity produced, and all have a hole in the centre from the spike on which they were originally kept. The ephemera were largely produced by the G. Gitton Printing Office but the file also contains ephemera attributed to his son G. R. Gitton, specifically for the Bridgnorth Theatre and Races. The G. Gitton Printing Office produced a variety of work for the town, including auction notices, certificates for the Providence Society for Sickness, verses for Sunday Schools, advertising bills, invoices and tickets for the bridges, alongside public notices that were printed to stop gossip or for public apologies, for example William Gouth, declaring that

\footnotetext{
${ }^{37}$ Bod, Bridgnorth Collection III.C. (14), The John Johnson Collection, Playbill printed by Partridge for Macbeth, King of Scotland, 1821; Bod, Bridgnorth Collection III.C. (469), The John Johnson Collection, Playbill printed by Gitton and Smith for Romeo \& Juliet, 1837.

${ }^{38}$ Bod, Bridgnorth Collection III.C. (485), The John Johnson Collection, Playbill printed by $C$. Edkins for Pizarro!, 1869.

${ }^{39}$ The National Archives of the UK (TNA), Series IR 1, Board of Stamps: Apprenticeship Books, UK, Register of Duties Paid for Apprentices, Indentures, 1710-1811.
} 
he had not had an affair with Isabella the wife of the local bricklayer John Rogers.

In his will, G. Gitton shared his inheritance between his adult children but the business passed to his son G. R. Gitton, who relocated the business to a more prominent dwelling..$^{40} \mathrm{~A}$ family feud between G. R. Gitton and his sister Catherine, documented in a series of public notices in the local and national newspapers, saw each sibling stating their claim to continue their father's business. ${ }^{41}$ Catherine set up as a rival printer but due to ill health was forced to take on William Smith as her business partner, who succeeded her in $1837 . .^{42}$

Although never formally apprenticed to his father, G. R. Gitton developed his printing skills in the family business and from an early age was responsible for printing playbills for the New Theatre. The relationship between the printer and the client is demonstrated in an 1821 letter from Stanton to G. R. Gitton. ${ }^{43}$ Here Stanton relays his instructions to Gitton for an advance order to advertise his forthcoming performances in Bridgnorth. The informal tone shows the close friendship and professional trust between the two men. Stanton provides minimal information for details of the performance, leaving the typographical and compositional decisions to the skills of the printer, as was usual at the time.

G. R. Gitton was twice made bankrupt, and had a weakness for drink, but he was an excellent printer and well-respected member of Bridgnorth society. His printing made great use of the newly available typefaces by London typefounders. In a playbill of 1832 for a production

\footnotetext{
${ }^{40}$ Mackarill, p. 45.

${ }_{41}^{41}$ 'Public announcement by Thomas Gitton, solicitor to the George Gitton estate', Aris's

Birmingham Gazette, 25 September 1826; 'Catherine Gitton's announcement of continuing her father's printing work', Aris's Birmingham Gazette, 13 November 1826.

${ }^{42}$ Mackarill, p. 46-7.

${ }^{43}$ Victoria and Albert Museum (V\&A), S.333-2016, Gabrielle Enthoven Collection, annotated playbill 'The Theatre, Oswestry', 1821.
} 
of Sheridan Knowles's The Hunchback at the New Theatre, Bridgnorth, G. R. Gitton used Caslon \& Livermore's Eight-Line Pica Condensed, an extremely bold sans serif used for dramatic effect. ${ }^{44}$ The comedy was billed as a headline attraction, promoted on its recent success in transforming the financial security of the Covent Garden Theatre in London. Coinciding with the Bridgnorth Races, Stanton's troupe performed a total of eleven different plays across the course of a week, with two plays presented each evening connected by an interval of musical entertainment. The Hunchback launched on the first race night of 1832 and concluded the following Wednesday. ${ }^{45}$

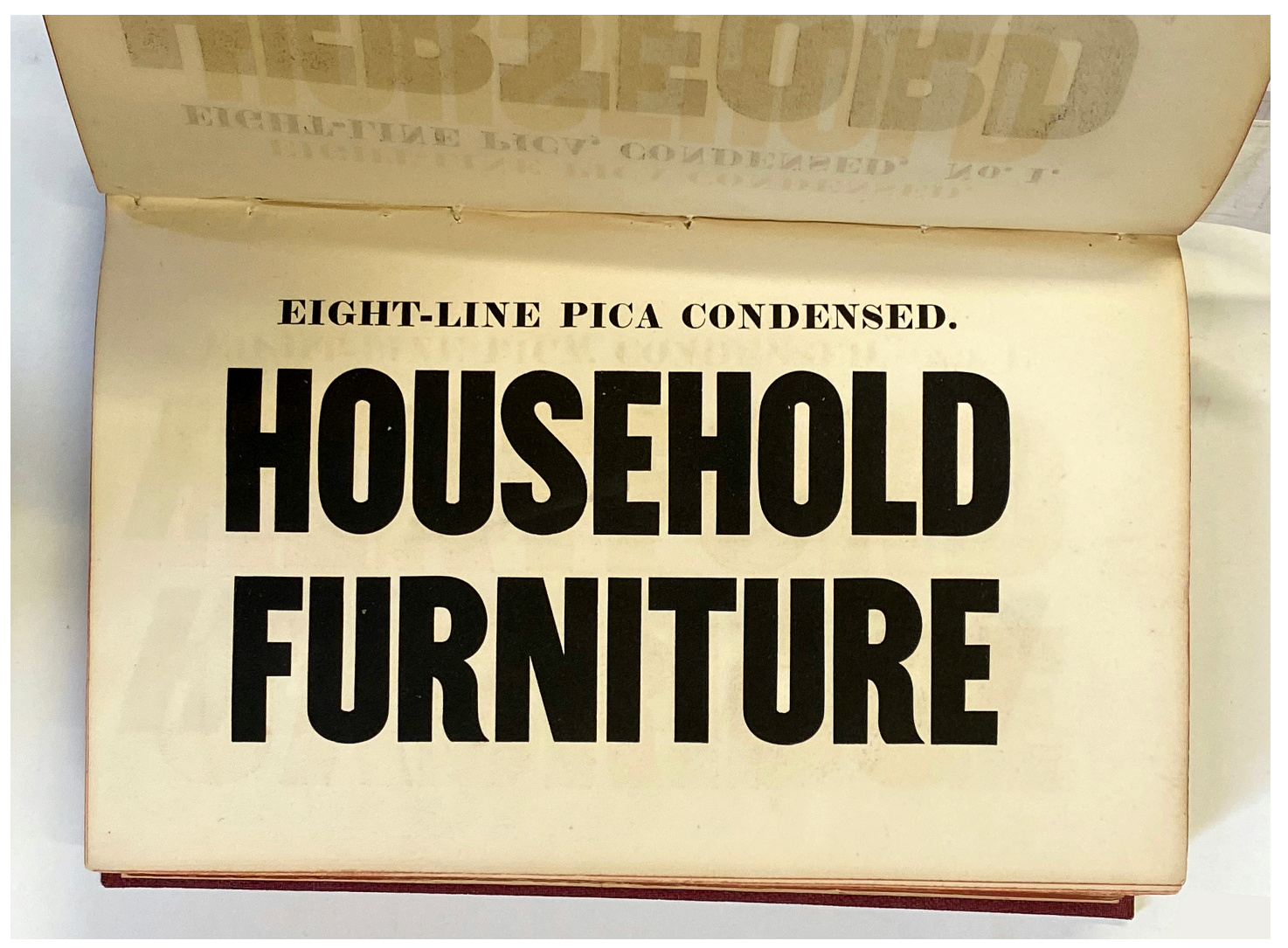

Figure 3: Eight-Line Pica Condensed, Specimen of Printing Types, Caslon \& Livermore, 1834, St Bride Library, London.

${ }^{44}$ SBL, Accession no. 438, Caslon \& Livermore, Specimen of printing types, 1834.

${ }^{45}$ CRL, PN 2596.B65, Bridgnorth Playbills Collection, New Theatre, Bridgnorth, 1832. 


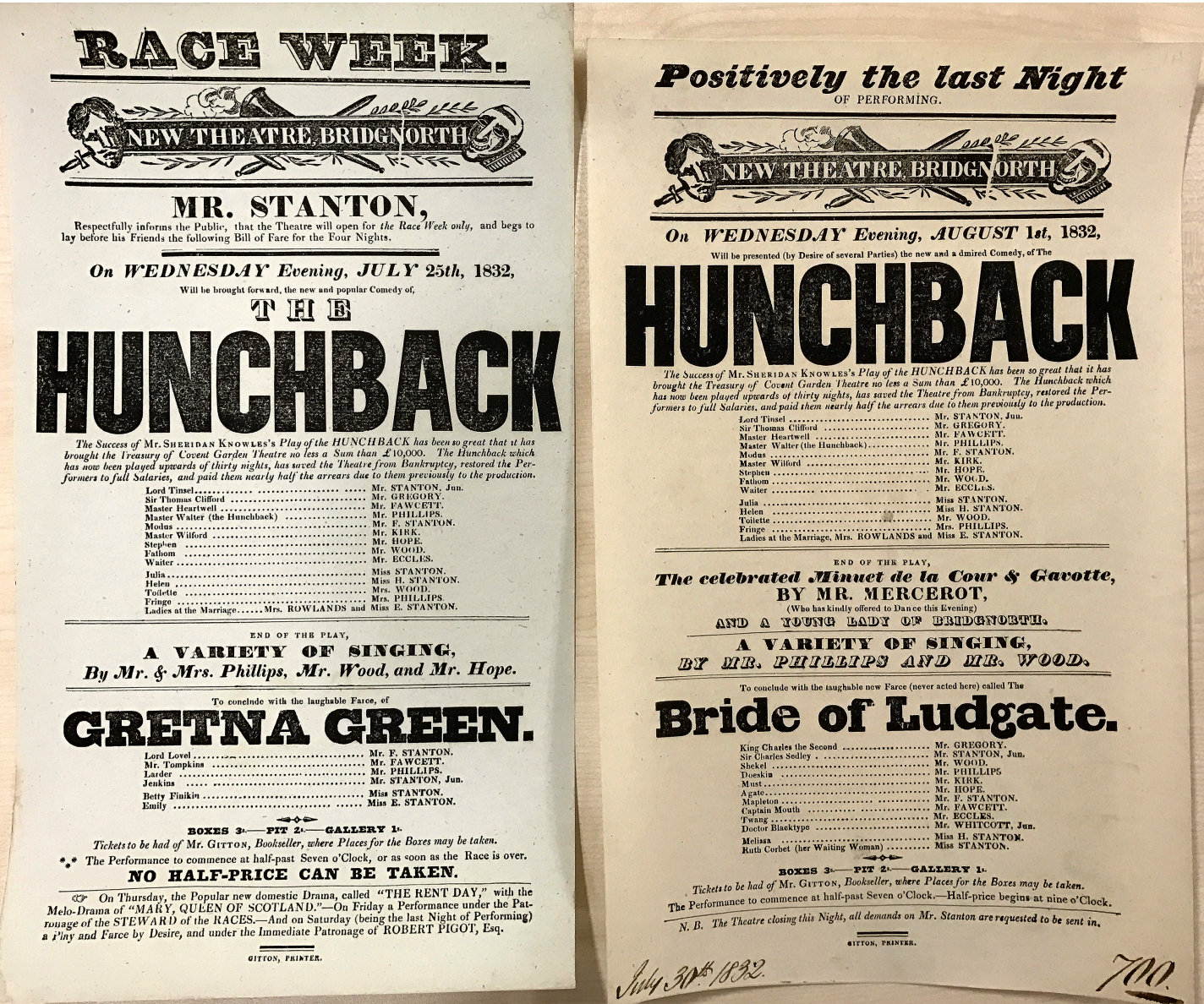

Figure 4: The Hunchback, New Theatre Bridgnorth, G. R. Gitton, 1832, Cadbury

Research Library: Special Collections, University of Birmingham.

G. R. Gitton's use of Caslon \& Livermore's sans serif was significant on several levels: he was innovative in his use of a heavyweight condensed sans serif as the primary level of visual hierarchy in the playbill; his playbills had dual functionality, being also used as handbills, of which the use of large display faces of this size was more familiar set within the composition of larger sizes of playbills and poster advertising; and it is of national significance that this is the first known use of Caslon \& Livermore's Eight-Line Pica Condensed: the typeface was not promoted in their specimen book until two years later in 1834. The use of this typeface demonstrates that G.R. Gitton was in direct communication with the London typefounders, and his readiness 
to take advantage of their latest designs. At 96-points, Eight-Line Pica Condensed was a very large attention-grabbing typeface. G. R. Gitton used the typeface again for a large-scale poster advertising the Bridgnorth Races. In doing so, he made a visual connection between the theatre performances and race activities, thereby presenting Bridgnorth as a visitor attraction. G. R. Gitton's use of Caslon \& Livermore's typeface is evidence that Bridgnorth printers were ahead of typographic fashions, buying the latest types as they were released, pre-ordering from London typefoundries. Locally, G. R. Gitton's printing influenced that of his regional contemporaries. In 1834, when The Hunchback was performed at the Theatre Royal, Birmingham, the printer Fredrick Turner also used the same typeface on his playbill, thus recognising the importance of Gitton's use of Eight-Line Pica Condensed as a successful typographic device and aid memoire for local audiences familiar with the earlier Bridgnorth performances. ${ }^{46}$

\section{Conclusion}

Jobbing printers who dared embrace the early sans serif printing types did not simply follow new typographic fashions they also led the way. Joesbury and G.R. Gitton both experimented with the new types in order to create a new visual language and original typographic solutions and as a result they helped refine and elevate jobbing printing.

Wrightson \& Webb applied the typographic conventions familiar in handbills and playbills to the advertisements in their directories. By developing a formal design system for the compositions of the adverts Wrightson \& Webb were early exponents for create visual identities or 'brands' for their clients. Watton and Joesbury's historical charts helped

\footnotetext{
${ }^{46}$ BL, General Reference Collection DRT Digital Store Playbills 193, A collection of playbills from Theatre Royal, Birmingham, 1834.
} 
progress educational publishing through the application of advertising typography to information design. By using large types and white space, key information was presented in a way that assisted in information recall and enabled the reading of young scholars. By embracing the latest display faces, G. R. Gitton departed from the typography used by earlier printers and produced an array of original advertising for Bridgnorth. W. Joesbury and G. R. Gitton's work in particular stands out from that of their contemporaries. By creating a new typographic language for their clients and customers they introduced local audiences to the emergent visual culture of modern advertising. As pioneers of new display typography, Gitton's refined the art of jobbing printing and explored new possibilities in the way in which typography could be used to represent trade and society. The work of W. Joesbury and G. R. Gitton is testimony to the innovation of these printers, whose contributions to jobbing printing positioned their work amongst the forefront of typographical developments of the nineteenth century. In their radical use of composition and through the application of the latest foundry typefaces, their work is of great significance, they influenced not only their contemporaries locally and nationally but also shaped the work of future generations of printers.

\section{Acknowledgments}

Thanks to my PhD supervisors Professor Caroline Archer, Birmingham City University, and Gerry Leonidas, University of Reading. Also, to Dr Malcolm Dick, University of Birmingham (UoB); Dr John Hinks and Dr Maureen Bell; Martin Killeen, Cadbury Research Library, UoB; the staff of the Wolfson Centre for Archival Research, Library of Birmingham; Emma Spencer, Branch Librarian, Bridgnorth Library; the volunteers of the Local History Centre, Bridgnorth, for allowing me to draw on their work of transcribing the George Robert Gitton diaries of 1838 and 1859; and the Shropshire Archives. 